\title{
LABOR SUPPLY ELASTICITY AND SOCIAL SECURITY REFORM
}

Selahattin İmrohoroğlu and Sagiri Kitao*

CRR WP 2009-5

Released: March 2009

Draft Submitted: January 2009

\author{
Center for Retirement Research at Boston College \\ Hovey House \\ 140 Commonwealth Avenue \\ Chestnut Hill, MA 02467
}

Tel: 617-552-1762 Fax: 617-552-0191

* Selahattin İmrohoroğlu is a professor in the department of finance and business economics at the University of Southern California. Sagiri Kitao is an assistant professor of finance and business economics at the University of Southern California. The research reported herein was pursuant to a Sandell grant from the U.S. Social Security Administration (SSA) funded as part of the Retirement Research Consortium (RRC). The findings and conclusions expressed are solely those of the authors and do not represent the views of SSA, any agency of the Federal Government, the RRC, the University of Southern California, or Boston College.

(C) 2009, by Selahattin İmrohoroğlu and Sagiri Kitao. All rights reserved. Short sections of text, not to exceed two paragraphs, may be quoted without explicit permission provided that full credit, including $\odot$ notice, is given to the source. 


\section{About the Center for Retirement Research}

The Center for Retirement Research at Boston College, part of a consortium that includes parallel centers at the University of Michigan and the National Bureau of Economic Research, was established in 1998 through a grant from the Social Security Administration. The Center's mission is to produce first-class research and forge a strong link between the academic community and decision makers in the public and private sectors around an issue of critical importance to the nation's future. To achieve this mission, the Center sponsors a wide variety of research projects, transmits new findings to a broad audience, trains new scholars, and broadens access to valuable data sources.

Center for Retirement Research at Boston College

Hovey House

140 Commonwealth Avenue

Chestnut Hill, MA 02467

phone: 617-552-1762 fax: 617-552-0191

e-mail: crr@bc.edu

crr.bc.edu

Affiliated Institutions:

The Brookings Institution

Massachusetts Institute of Technology

Syracuse University

Urban Institute 


\begin{abstract}
Previous literature on social security reform has used a variety of period utility functions and calibrated values for the intertemporal elasticity of substitution (IES) in labor. In this paper, we extensively study various preferences and values for IES in a general equilibrium model with overlapping generations. We calibrate the model to key U.S. macroeconomic indicators and document how social security reform impacts the economy under different preferences. We find that aggregate effects are surprisingly similar, regardless of the wide range of the values of IES used. However, reform leads to a life-cycle reallocation of work hours from early years to later working years and the size of this reallocation significantly increases with the IES.
\end{abstract}




\section{Introduction}

The unfunded social security system in the United States has been quite resilient to various reform proposals. Even though a large body of research suggests that it introduces significant distortions in private saving and labor supply and may not be an efficient institution to allocate various risks that the individuals face, it has had wide popular support. ${ }^{1}$ One strand points out to political economy reasons for the introduction and maintenance of the unfunded system. ${ }^{2}$ Another line of research argues that transitional costs to a reformed system seem to be large. ${ }^{3}$ In a recent paper, Nishiyama and Smetters (2007) argue that partial (50\%) privatization of social security is likely to bring an overall efficiency loss in an economy populated with households facing uninsurable income and longevity risks. As a result, the extent to which formal or informal insurance arrangements exist and the strength of response in labor supply appear to be critical in understanding the macroeconomic and welfare consequences of social security reform.

In all this previous literature, different utility functions with different calibration targets and therefore different labor supply elasticities have been used to examine the quantitative implications of reforming the current PAYGO system. In this paper, we extensively analyze the impact of the intertemporal elasticity of labor supply (IES) on how social security reform affects the aggregate results, life-cycle profiles and welfare. We use an economic environment commonly employed in recent studies of social security reforms, adopt a common set of calibration targets, and systematically document the quantitative findings as a function of the period utility function and the IES. The estimates of IES, also known as the Frisch elasticity of labor supply, in the literature range from the early estimates of about 0.1-0.5 to the more recent estimate by Imai and Keane (2004) of more than 3. Although most of the recent estimates of this crucial parameter are centered around unity, we will consider values of this parameter ranging from 0.1 to 2.0 in our analysis.

We use a general equilibrium model populated by overlapping generations of heterogeneous households facing uncertain lifespan and uninsurable income risks and borrowing constraints. They choose consumption and hours worked until a

\footnotetext{
${ }^{1}$ For example, see Feldstein (1985), Hubbard and Judd (1987), İmrohoroğlu, İmrohoroğlu, and Joines (1995) and İmrohoroğlu, İmrohoroğlu, and Joines (2003).

${ }^{2}$ See Cooley and Soares (1999), Boldrin and Rustichini (2000) and Casamatta, Cremer, and Pestieau (2002) among others.

${ }^{3}$ For example see Huang, İmrohoroğlu, and Sargent (1997), De Nardi, İmrohoroğlu, and Sargent (1999), Kotlikoff, Smetters, and Walliser (1999), Conesa and Krueger (1999), and Fuster, İmrohoroğlu, and İmrohoroğlu (2007).
} 
mandatory retirement age. The benefit and taxation rules of social security are implemented according to the formulas used by the Social Security Administration (SSA). The fiscal authority taxes capital and labor income and consumption to finance an exogenous quantity of government purchases and interest payments on its debt. We calibrate the model to some key statistics from the post World War II U.S. economy. We then conduct counterfactual experiments by reforming social security, either by downsizing the system by $50 \%$, or by totally eliminating it.

Our main quantitative finding is that social security reform leads to surprisingly similar aggregate outcomes for a wide range of the IES. For example, when we take IES as 0.1 , half privatization leads to an increase of $9.6 \%$ in the capital stock, a decrease of $0.02 \%$ in the average work hours and a decrease of $4.7 \%$ in the budgetclearing labor income tax rate, whereas the changes are $8.1 \%,-0.22 \%$ and $-4.6 \%$, respectively, when the IES is taken as 1.0, a ten-fold increase in the intertemporal responsiveness of labor. Long-run welfare is somewhat different: individuals more strongly prefer to be born into the reformed steady-state; they are willing to give up $1.9 \%$ and $2.3 \%$ consumption, respectively, in the unfunded steady-state in order to be born in the reformed one. However, these similarities at the aggregate level hide significant differences in the allocation of work hours over the life-cycle. With reform (half privatization) individuals shift work from the early years in the lifecycle to later years, regardless of the IES. However, with an IES equal to unity, this reallocation is quantitatively much more significant than that in the case of an IES of 0.1 . This reallocation is even larger in the case of full privatization. Therefore, the IES used in a study of social security reform leaves the aggregate implications unchanged to a large extent in the long run, but matters significantly when analyzing the life-cycle implications of the reform. ${ }^{4}$

The remainder of the paper is organized as follows. We present the model economy in section 2. The calibration details are given in section 3. Section 4 presents our numerical findings. Section 5 conducts a sensitivity analysis and concluding remarks are given in section 6 .

\footnotetext{
${ }^{4}$ Rogerson and Wallenius (2007) find large macro elasticities, 2.25 to 3 , when they vary the IES from 0.05 to 1.25 in an experiment in which the labor income tax rate is raised from $30 \%$ to $50 \%$ with the proceeds returned in a lump sum fashion. They use a continuous time life cycle model of a complete market with no borrowing constraint in which individuals choose not only the hours worked but also the fraction of the life cycle spent in market activities. The decrease in aggregate hours worked is essentially the same for any IES in the range they consider. However, the hours profile is affected more significantly.
} 


\section{Model}

\subsection{Demographics}

In each period the economy is populated by overlapping generations of individuals of age $j=1,2, \ldots, J$, who face lifespan uncertainty until the maximum possible age $J$. We denote the conditional probability of survival from age $j$ to age $j+1$ with $s_{j}$. We have $s_{J}=0$. The size of new cohort grows at a constant rate $n$. Accidental bequests are collected and distributed as a lump-sum transfer to the entire population. We restrict our attention to steady-states and omit all time subscripts.

\subsection{Endowments and preferences}

Households enter the economy with no assets. They are endowed with one unit of time that can be used for leisure or market work. Households' earnings are given by $w \varepsilon_{j} \eta \ell$, where $w$ is the market wage, $\varepsilon_{j}$ is the age-specific productivity, $\eta$ is an idiosyncratic labor productivity that evolves stochastically, and $\ell$ is the endogenously chosen hours of work.

Households order the sequences of consumption and labor supply over the lifecycle according to a time-separable utility function

$$
E\left\{\sum_{j=1}^{J} \beta^{j-1} u\left(c_{j}, \ell_{j}\right)\right\},
$$

where $\beta$ is the subjective discount factor and the expectation is with respect to the shocks associated with the time of death and idiosyncratic labor productivity, and consumption and labor supply at age $j$ are denoted by $c_{j}$ and $\ell_{j}$, respectively.

\subsection{Technology}

There is a representative firm that runs a constant returns to scale technology of the form $Y=F(A, K, L)=K^{\alpha}(A L)^{1-\alpha}$, where $K$ and $L$ are aggregate capital and labor inputs and $\alpha$ is capital's share of output. $A$ is an exogenous labor-augmenting technological change that grows at the constant rate $g$. Capital depreciates at a constant rate $\delta \in(0,1)$. The firm rents capital and hires labor from households in competitive markets, where factor prices $r$ and $w$ are equated to the marginal productivities. 


\subsection{Social security}

In the benchmark economy, the government operates a pay-as-you-go pension system similar to the current U.S. system. Working households pay a proportional tax $\tau^{s s}$ on their labor income up to the maximum amount of $y^{s s}$, after which the social security tax rate is zero. Each retired agent receives the benefit $s s$, which is a concave function of an individual's average lifetime earnings that captures the progressivity of the U.S. social security system. The benefit is constant over the remaining lifespan of an individual but it increases every year by the rate of exogenous productivity growth as in the current U.S. system. We will consider different reforms in the direction of a privatized system in section 4 .

\subsection{Market structure}

The markets are incomplete and households cannot insure against the idiosyncratic labor income and mortality risks by trading state-contingent assets. They can, however, hold one-period riskless assets to imperfectly self-insure against idiosyncratic risks. We assume that agents are not allowed to borrow against future income, i.e. $a_{j} \geq 0$ for all $j$.

\subsection{Households Problem}

Households are heterogeneous in four dimensions summarized by a state vector $x=$ $\{j, a, \eta, e\}$, where age is $j$, assets accumulated in the previous age are denoted by $a$, the idiosyncratic labor productivity is $\eta$, and $e$ represents the cumulated labor earnings that determine the retirement benefit.

We compute the household's problem recursively. The value function $V(x)$ of an individual in state $x$ is given by

$$
V(j, a, \eta, e)=\max _{c, \ell, a^{\prime}}\left\{u(c, \ell)+\beta s_{j} E\left[V\left(j+1, a^{\prime}, \eta^{\prime}, e^{\prime}\right)\right]\right\}
$$

subject to

$$
\begin{aligned}
& c+a^{\prime}=(1+r)(a+b)+w \varepsilon_{j} \eta \ell+s s(x)-\Upsilon(x), \\
& a^{\prime} \geq 0, \\
& e^{\prime}=\left[(j-1) e+w \varepsilon_{j} \eta \ell\right] / j, \text { for } j<j_{R}, \\
& e^{\prime}=e, \text { for } j \geq j_{R},
\end{aligned}
$$


where $\Upsilon(x)$ denotes the taxes paid by a household in state $x$. The cumulated labor earnings $e$ evolves according to the sequence of the realization of labor productivity shocks and endogenously chosen hours of work profile.

\subsection{Fiscal policy}

Besides the social security tax, the government raises revenue from taxes on labor income, capital income and consumption at proportional rates denoted by $\tau^{\ell}, \tau^{a}$ and $\tau^{c}$, and issues one-period riskless debt $D^{\prime}$. The government debt and tax revenue finance the payment of pensions for the retired, an exogenously given level of public purchases of goods and services $G$ and the servicing and repayment of the debt. The labor income tax rate $\tau^{\ell}$ is set so that the following consolidated government budget constraint is satisfied every period.

$$
\begin{aligned}
& G+(1+r) D+\sum_{x} s s(x) \mu(x)=\sum_{x}\left[\tau^{\ell} w \varepsilon_{j} \eta \ell(x)+\tau^{s s} \min \left\{w \varepsilon_{j} \eta \ell(x), y^{s s}\right\}\right. \\
& \left.+\tau^{a} r(a(x)+b)+\tau^{c} c(x)\right] \mu(x)+D^{\prime}
\end{aligned}
$$

where $\mu(x)$ denotes the measure of individuals in state $x, D$ is the debt issued in the previous period and $D^{\prime}$ is the proceeds of the debt issued in the current period.

\subsection{Equilibrium}

For a given set of exogenous demographic parameters $\left\{s_{j}\right\}_{j=1}^{J}$ and $\{n\}$ and government policy variables $\left\{G, D^{\prime}, s s, \tau^{s s}, \tau^{a}, \tau^{c}\right\}$, a stationary competitive equilibrium consists of households' decision rules $\{c(x), \ell(x), a(x)\}$ for each state $x$, factor prices $\{w, r\}$, labor income tax rate $\left\{\tau^{\ell}\right\}$, a lump-sum transfer of accidental bequests $\{b\}$ and the measure of individuals $\{\mu(x)\}$ that satisfy the following conditions:

1. Households' allocation rules solve their recursive optimization problems defined in section 2.6.

2. Factor prices are determined competitively, i.e. $w=F_{L}(A, K, L)$ and $r=$ $F_{K}(A, K, L)-\delta$.

3. The lump-sum bequest transfer is equal to the amount of assets left by the deceased.

$$
b=\sum_{x} a(x)\left(1-s_{j-1}\right) \mu(x)
$$


4. The labor and capital markets clear.

$$
\begin{aligned}
L & =\sum_{x} \varepsilon_{j} \eta \ell(x) \mu(x), \\
K & =\sum_{x}(a(x)+b) \mu(x)-D .
\end{aligned}
$$

5. The labor income tax satisfies the government budget constraint defined in equation (1).

6. The goods market clears.

$$
\sum_{x} c(x) \mu(x)+K^{\prime}+G=Y+(1-\delta) K
$$

\section{Calibration}

\subsection{Demographics}

One model period corresponds to a year. We assume that households enter the economy at age $20(j=1)$, retire from work at age $65\left(j_{R}=46\right)$ and live up to the maximum age of $100(J=81)$. We use the study of Bell and Miller (2005) for the current age-dependent conditional survival probabilities in the U.S. We set the growth rate $n$ of the new entrants to the economy to $1.69 \%$ so that we match the old dependency ratio of $20 \%$ in 2005 , defined as the ratio of the population aged 65 and over to that between 20 and 64 .

In section 5, we recompute and simulate the model with demographics that approximate long-run projections and study the sensitivity of our results to the demographic change. According to the Social Security Administration (SSA), the dependency ratio will exceed $40 \%$ by 2080 . We use SSA's projected survival rates for 2080 (Bell and Miller, 2005) and the population growth rate of $0.1 \%$ that together generate the dependency ratio of $40 \%$.

\subsection{Preferences, endowments and technology}

Preferences: We assume that the instantaneous utility function takes the form

$$
u(c, \ell)=\log (c)-\chi \frac{\ell^{1+\frac{1}{\gamma}}}{1+\frac{1}{\gamma}},
$$


where $\chi$ represents the weight on the disutility from work relative to the utility from consumption. When preferences are given by (6), the IES is constant over the lifecycle and is given by $\gamma$. In section 5 , we study the sensitivity of our results to other forms of utility functions. In particular, we simulate the model with separable and non-separable preferences defined over consumption and leisure, both of which are often used in the literature. The subjective discount factor $\beta$ is calibrated to match a capital-output ratio of 2.43 in the initial steady state, which is based on private fixed capital excluding durables. The parameter $\chi$ is chosen to yield a fraction of hours worked equal to 0.33 .

Endowments: Households' labor efficiency depends on two components. The deterministic age-dependent component $\varepsilon_{j}$ is taken from Hansen (1993). The idiosyncratic component $\eta$ is specified as a first-order autoregressive process with a persistence parameter $\rho=0.94$ and the variance of the white noise $\sigma^{2}=0.02$, which lie in the range of estimates in the literature (see, for example, Heathcote, Storesletten and Violante, 2004). We approximate this continuous process with a five-state, first-order discrete Markov process.

Technology: We assume the labor-augmenting technological growth at an exogenous rate of $g=1.65 \%$, close to the average in 1950-2000. The income share of capital $\alpha$ is set at $0.33 .^{5}$ The depreciation rate $\delta$ is $0.069=\frac{X / Y}{K / Y}-g-n-g n$, which is implied by the equilibrium law of motion for the capital in the steady state, where we target an investment-output ratio $X / Y$ of $25 \%$ and a capital-output ratio $K / Y$ of 2.43 .

\subsection{Social security and fiscal policy}

In the initial steady state, the government runs a pay-as-you-go social security program that captures the features of the system in the U.S. We set the social security tax rate $\tau^{s s}$ at $10.6 \%$ with the maximum taxable amount of $y^{s s}=\$ 97,500$ as it is in

\footnotetext{
${ }^{5}$ Consistently with the target capital-output ratio, this measure is based on private fixed capital only and excludes government capital and the stock of durables. As part of a sensitivity analysis, we consider a broader definition of capital and the resulting measure of output. In particular, we add the stock of consumer durables and government capital to private fixed capital and the service flows from these two additional items to measured GDP. With this new matching of model and NIPA accounts, we calculate the corresponding share of capital in output and the capital output ratio as 0.43 and 2.94, respectively. Since our main results are not affected, we do not report the results in the paper. They are available from authors upon request.
} 
the U.S. in 2007. The benefit is a concave piecewise linear function of the average lifetime earnings ("AIME"). The marginal replacement rate is $90 \%$ for the average earnings up to $20 \%$ of the economy's average earnings, above which the replacement rate falls to $32 \%$. For income between $123 \%$ and $202 \%$ of the economy's average, the replacement rate is $15 \%$. Additional income above $202 \%$ of the economy's average does not provide additional pension benefit. ${ }^{6}$

In the initial benchmark economy, we set the government spending $G$ at $20 \%$ of output, which is the average ratio of government consumption expenditures and investment to GDP in the post-war period. The ratio of federal debt held by the public to GDP is set at 40\%. We assume a consumption tax rate of $5 \%$ and a capital income tax rate of $30 \%$. The labor income tax is set so that the government budget constraint is satisfied.

\section{Results}

\subsection{Benchmark simulations}

In order to understand how labor supply elasticity affects the quantitative results of social security reform, we numerically characterize three steady-state economies. First, in what we call a benchmark economy, the government operates a pay-asyou-go social security system as described in section 3.3. The other two economies differ in the way the fiscal authority deals with the public pension system. The first economy assumes that the benefits and social security tax rate are cut by $50 \%$, which we call half privatization. The second assumes a complete elimination of the unfunded social security system, which we call full privatization. In both economies, the debt-to-GDP ratio is held constant at the benchmark level, and any financial discrepancy between the government's consolidated tax revenues and expenditures are financed by a higher (or lower) labor income tax rate. We follow the literature and keep all experiments revenue-neutral by keeping the exogenous public spending $G$ fixed across three economies.

We compare the effects of social security reforms along two dimensions. First, we describe the effects on aggregate macroeconomic indicators. Second, we document the effects on the allocation of consumption, assets, and labor supply over the lifecycle. In all cases, we consider various labor supply elasticities to investigate the role played by this important preference parameter on both macro and micro results.

\footnotetext{
${ }^{6}$ This is based on the Primary Insurance Amount formula with bend points of $\$ 627$ and $\$ 3,779$, the maximum monthly benefit of $\$ 1,939$ and national average wage index of $\$ 36,952$, all in 2005 .
} 
Table 1 summarizes the aggregate effects of the social security reforms when we employ preferences of the form $u(c, \ell)=\log (c)-\chi \ell^{1+1 / \gamma} /(1+1 / \gamma)$, where $\gamma$ is the Frisch elasticity of labor supply. We compute three steady-state economies for each of four alternative values of Frisch labor supply elasticity, ranging from 0.1 to 2.0. For each model, we recalibrate the parameters of the model in order to match the same aggregate statistics that we described in section 3 .

Table 1: Aggregate effects of social security reforms

\begin{tabular}{|c|c|c|c|c|}
\hline IES $\gamma$ & 0.1 & 0.5 & & 2.0 \\
\hline \multicolumn{5}{|l|}{ PAYGO system (Benchmark) } \\
\hline Interest rate $(\%)$ & $6.7 \%$ & $6.7 \%$ & $6.7 \%$ & $6.7 \%$ \\
\hline Labor income tax: $\tau^{l}+\tau^{s s}(\%)$ & $27.3 \%$ & $27.4 \%$ & $27.4 \%$ & $27.5 \%$ \\
\hline \multicolumn{5}{|l|}{ Half privatization } \\
\hline Capital & $+9.6 \%$ & $+8.9 \%$ & $+8.1 \%$ & $+7.2 \%$ \\
\hline Labor & $+0.02 \%$ & $-0.07 \%$ & $-0.12 \%$ & $-0.12 \%$ \\
\hline Average work hours & $-0.02 \%$ & $-0.16 \%$ & $-0.22 \%$ & $-0.23 \%$ \\
\hline Wage & $+3.1 \%$ & $+2.9 \%$ & $+2.7 \%$ & $+2.4 \%$ \\
\hline Interest rate $(\%)$ & $5.9 \%$ & $5.9 \%$ & $6.0 \%$ & $6.0 \%$ \\
\hline Labor income tax: $\tau^{l}+\tau^{s s}(\%)$ & $22.6 \%$ & $22.7 \%$ & $22.8 \%$ & $22.9 \%$ \\
\hline Long-run welfare: CEV (\%) & $1.9 \%$ & $2.0 \%$ & $2.3 \%$ & $2.6 \%$ \\
\hline \multicolumn{5}{|l|}{ Full privatization } \\
\hline Capital & $+24.7 \%$ & $+22.6 \%$ & $+20.7 \%$ & $+18.4 \%$ \\
\hline Labor & $-0.02 \%$ & $-0.24 \%$ & $-0.36 \%$ & $-0.38 \%$ \\
\hline Average work hours & $-0.11 \%$ & $-0.45 \%$ & $-0.60 \%$ & $-0.60 \%$ \\
\hline Wage & $+7.6 \%$ & $+7.1 \%$ & $+6.5 \%$ & $+5.9 \%$ \\
\hline Interest rate $(\%)$ & $4.8 \%$ & $4.9 \%$ & $5.0 \%$ & $5.2 \%$ \\
\hline Labor income tax: $\tau^{l}+\tau^{s s}(\%)$ & $17.8 \%$ & $17.9 \%$ & & $18.2 \%$ \\
\hline Long-run welfare: CEV (\%) & $2.5 \%$ & $3.0 \%$ & & $4.5 \%$ \\
\hline
\end{tabular}

\section{Aggregate effects of a typical social security reform}

Before we analyze the role played by the intertemporal elasticity of supply in labor in affecting the long-run effects of social security reforms, it will be useful to describe the typical effects of social security reform for a given value of IES. We focus on the shaded column labeled $\mathbf{1 . 0}$ (for IES) of Table 1 that describes the effects of two 
possible reforms in which the social security policy is different.

When we use an IES equal to 1.0, a reform of the unfunded retirement system delivers long-run gains. Half privatization leads to a decrease in the combined labor income tax rate $\tau^{l}+\tau^{s s}$, from the initial $\mathbf{2 7 . 4} \%$ to $\mathbf{2 2 . 8} \%$. Since the households are now forced to partially support their own old age consumption, they increase their private saving and the capital stock shows an increase of $\mathbf{8 . 1 \%}$. However, the impact on labor market aggregates is very small. There is a marginal decrease in average hours worked $(-\mathbf{0 . 2 2} \%)$ and the decline in the aggregate labor supply is only $\mathbf{0 . 1 2} \%$. Aggregate capital becomes more abundant relative to the labor input of the economy and the interest rate falls from $\mathbf{6 . 7 \%}$ to $\mathbf{6 . 0} \%$, while the wage rate increases by $2.7 \%$.

Full privatization amplifies the effects on private saving and aggregate capital stock since the households are now entirely responsible for their old age consumption. The capital stock increases by $\mathbf{2 0 . 7 \%}$. The combined tax rate on labor supply

decreases further down to $\mathbf{1 8 . 1 \%}$, mostly due to the elimination of the $\mathbf{1 0 . 6} \%$ social security tax. There is a small decrease in average hours worked and aggregate labor supply. These numerical findings are similar to those in the previous literature that study the effects of social security reform towards a fully-funded system.

\section{Labor Supply Elasticity and the effects of reform}

We now turn our attention to the effects of reforms across models with different labor supply elasticities and examine Table 1 in its entirety. We find that the magnitude of the responses in aggregate labor supply and average hours of work are surprisingly similar. With full privatization, for example, the change in aggregate labor is negligibly small, lying in the range of $-0.02 \%$ to $-0.38 \%$ and average work hours fall by very little, in the range of $0.11 \%$ to $0.60 \%$. These numerical findings are in line with the U.S. facts documented by McGrattan and Rogerson (2004). Using data from the U.S. Bureau of the Census decennial censuses from 1950 to 2000, McGrattan and Rogerson show that "... there has been a negligible change in average hours per person at the aggregate level." Our model's result is analogous to this observation, regardless of the value of the IES, and we explore this point further below.

Hidden, however, behind the relatively small effects of different elasticities on aggregate labor supply are fairly large effects on the distribution of hours over the life-cycle. Left panels of Figure 1 show the age-hours profiles for values of IES equal to $0.1,0.5$ and 1.0 , respectively. For example, with a labor supply elasticity of 1.0 which is quite common in the literature on social security reform in models with 
nonseparable CRRA preferences, full privatization yields a very large reallocation of hours over the life-cycle, significantly reducing them at younger ages and raising them at mid- to old-ages. This finding suggests that the introduction of an unfunded social security system in the U.S. may explain, in part, the observed reallocation of hours over the life-cycle. Chart 1 in McGrattan and Rogerson (2004) (pp. 26) indicates that there has been a significant shift of hours worked from late ages before retirement to earlier ages over the life-cycle. In the bottom left plot of Figure 1 the patterns of work hours in the profile labeled 'PAYGO system' and 'Full Privatization' seem to be consistent with the hours profiles for the cohorts born in 1976-85 and 1866-75, respectively, that are presented in Chart 1 in McGrattan and Rogerson (2004). ${ }^{7}$

\footnotetext{
${ }^{7}$ McGrattan and Rogerson (2004) also document a decline of hours worked between 20-25 among the younger cohorts. This may be due to the increase over time in educational attainment and on-the-job skill accumulation. Our model abstracts from these factors and therefore we do not get this decline.
} 


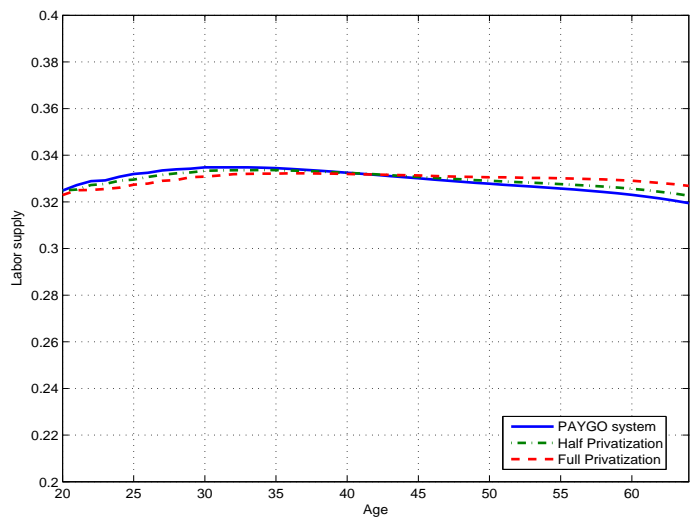

(a) Labor supply with $\gamma=0.1$

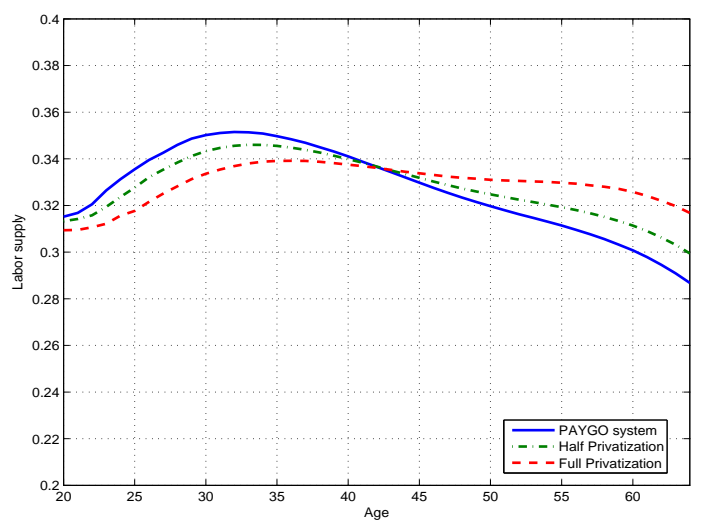

(c) Labor supply with $\gamma=0.5$

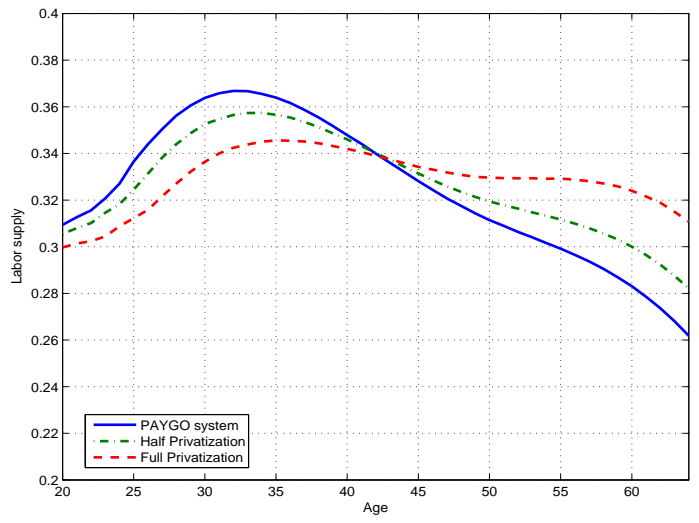

(e) Labor supply with $\gamma=1.0$

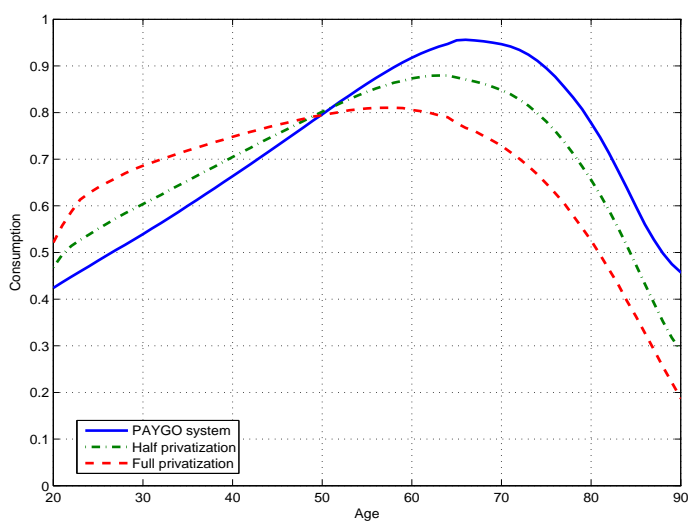

(b) Consumption with $\gamma=0.1$

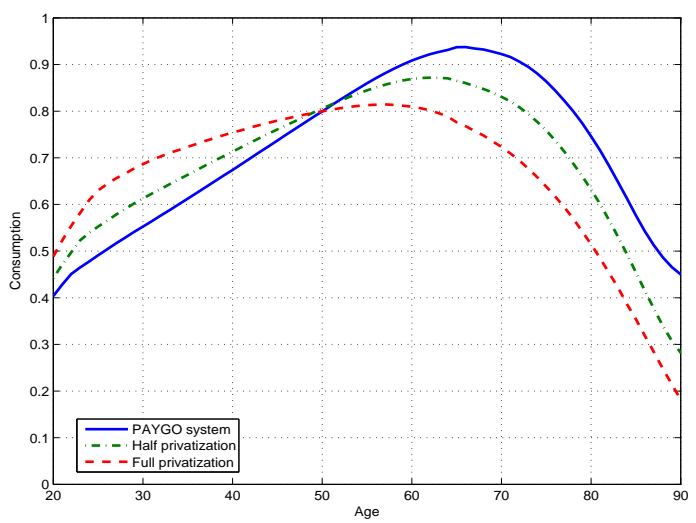

(d) Consumption with $\gamma=0.5$

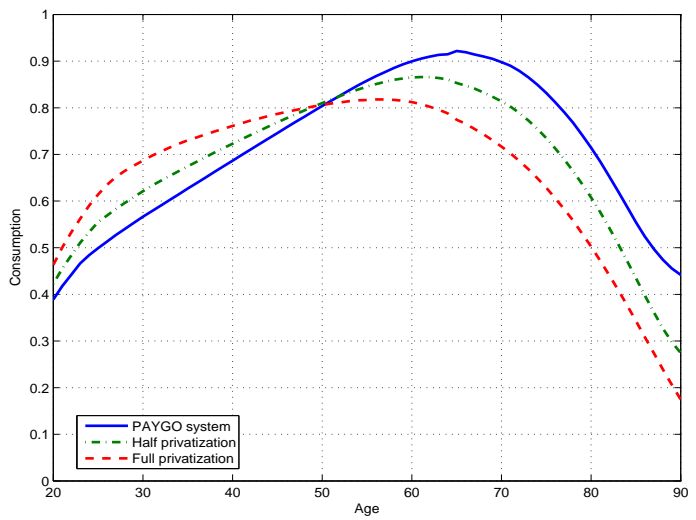

(f) Consumption with $\gamma=1.0$

Figure 1: Labor supply and consumption over the life-cycle: benchmark, half privatization and full privatization 
It will be useful to explore the reasons behind this reallocation of hours over the life-cycle and its sensitivity to IES. Notice that there is a very small quantitative difference in the change in the interest rate across different models, which ranges from $4.8 \%$ under full privatization with an IES of 0.1 to $5.2 \%$ with an IES equal to 2.0 , relative to $6.7 \%$ in the benchmark economy. The decrease in the interest rate induces the households to choose a much flatter path of consumption as optimal, a path that is similar across different labor supply elasticities as shown in the right panels of Figure 1. The same economic forces also flatten the age-hours profile, but the impact on the allocation of hours can vary across models with different elasticities. One can describe intuition behind this result by examining a simplified version of the first order conditions, ignoring productivity uncertainty, the marginal effect on the social security benefits, and borrowing constraints. The intertemporal and intratemporal optimality conditions are given as

$$
\begin{aligned}
u^{\prime}\left(c_{j}\right) & =u^{\prime}\left(c_{j+1}\right) \beta s_{j}\left\{1+r\left(1-\tau^{a}\right)\right\} \\
u^{\prime}\left(c_{j}\right)\left(1-\tau^{\ell}\right) \varepsilon_{j} w & =v^{\prime}\left(\ell_{j}\right),
\end{aligned}
$$

where $u^{\prime}\left(c_{j}\right)$ denotes the marginal utility from consumption and $v^{\prime}\left(\ell_{j}\right)$ the marginal disutility of work, at age $j$. Using the preference specification we employed and combining the two equations, we have

$$
\frac{\varepsilon_{j+1}}{\varepsilon_{j}} \frac{\ell_{j}}{\ell_{j+1}}=\left[\beta s_{j}\left\{1+r\left(1-\tau^{a}\right)\right\}\right]^{\gamma}=\left\{\frac{c_{j+1}}{c_{j}}\right\}^{\gamma} .
$$

Given our calibration of $\beta$ to match the common capital-output ratio in each model, $\beta\left\{1+r\left(1-\tau^{a}\right)\right\}>1.0$ for all the models that we considered. ${ }^{8}$

Therefore a lower interest rate (resulting from the increase in the capital-labor ratio due to social security reform) will flatten both the age-consumption and the age-hours profiles, but the latter with a greater intensity if the IES $\gamma$ is larger. In order to highlight the difference, Figure 2 plots the ratio of hours profiles in reform economies to that of the benchmark economy. The labor supply of households in a year before retirement is higher by as much as $18 \%$ in the case of $\gamma=1.0$ under full privatization. This is a very large reallocation of hours over the life-cycle in response to social security reform. The change, however, is $10 \%$ with $\gamma=0.5$ and only a few

\footnotetext{
${ }^{8}$ The value of $\beta$ that is calibrated to match the common capital-output ratio in the benchmark of different models lies in the narrow range between 0.988 with $\gamma=0.1$ and 0.980 with $\gamma=2.0$. The conditional survival probabilities are high and close to unity during working ages, lying above 0.99 until age 62 . Therefore the optimal growth rate of consumption before retirement is positive even after taking into account the additional discounting by death probabilities.
} 
percentage points with $\gamma=0.1$. The decrease in aggregate labor supply is smaller than the decrease in average work hours, since those mid- to old-age agents who increase work hours are more productive and contribute more per hour than the younger agents who reduce work hours, raising the average productivity of workers.

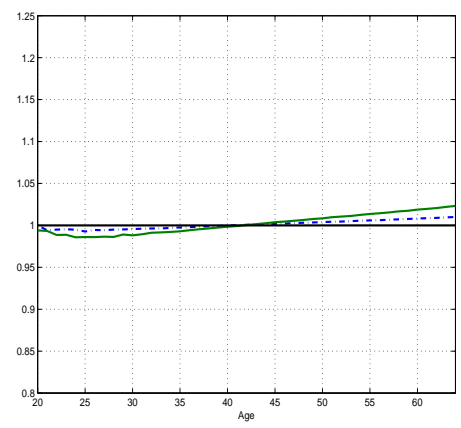

(a) $\gamma=0.1$

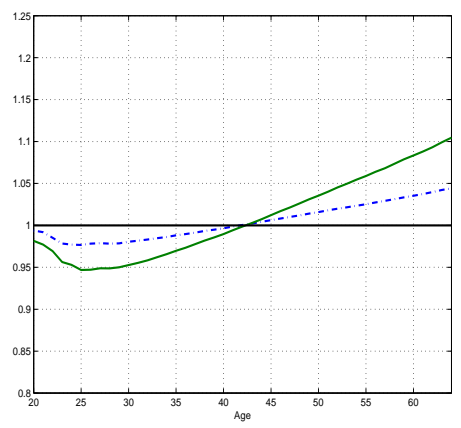

(b) $\gamma=0.5$

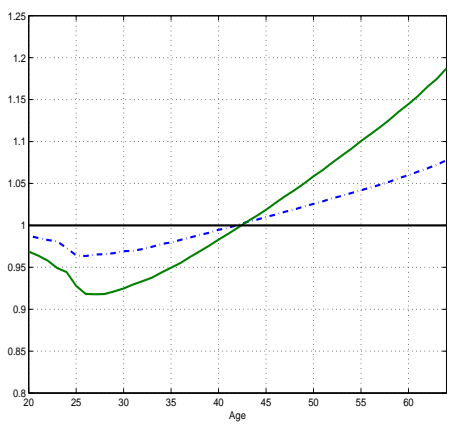

(c) $\gamma=1.0$

Solid lines represent the labor supply under full privatization relative to the benchmark PAYGO system and dashed lines represent half privatization.

Figure 2: Changes in labor supply over the life-cycle

Although the effect on the age-consumption profile is nearly identical across models, the increase in aggregate capital is larger with lower elasticities. To understand the reason, note that the need to save and finance one's retirement consumption in the face of reduced or eliminated public pension is met by the combination of lower consumption before reaching the retirement age and earnings by additional market hours. With a higher labor supply elasticity, the second adjustment is used more extensively as households are more willing to intertemporally substitute labor. As we saw in Figure 1, with a higher labor supply elasticity, households work and earn more at older ages to meet the additional need for retirement savings. Therefore compared to the case of a very low elasticity where the hours profile barely changes, there is less need for them to start accumulating wealth at younger ages by cutting back the consumption. Put differently, the life-cycle saving motive becomes more pronounced when the labor supply elasticity is small and this causes the aggregate capital stock to increase by a larger percentage in response to social security reform for small values of IES.

In Table 1, the last rows of the privatization experiments present the long-run welfare effects of the two social security reforms relative to the benchmark economy with pay-as-you-go social security system. They are computed as consumption 
equivalent variations from the ex-ante perspective of a newborn household in the economy. It measures the percentage increase in consumption across all possible states of the benchmark economy that makes the household indifferent between the economies with and without reform. A positive number implies households are better off under the reform economy. With a higher labor supply elasticity, the age-hours profile responds more to the change in the interest rate without incurring as much utility cost as it would under the low labor supply elasticity. Ex-post, the distribution of work hours across ages is smoother and flatter compared to the benchmark economy, which because of the convexity in the disutility of labor, improves welfare.

\section{$5 \quad$ Sensitivity analysis and extensions}

\subsection{Sensitivity to preference specifications}

The period utility function (6) used in the previous section is quite common in the applied labor literature but not in the social security reform literature. However, it has the convenient property that the IES is constant over the life-cycle. In this section, we consider two alternative forms of period utility functions and study the sensitivity of our results to these preference specifications. The first is a separable preference defined over consumption and leisure, commonly used in the real business cycle literature, given as

$$
u(c, 1-\ell)=\log (c)+\psi \frac{(1-\ell)^{1-\theta}}{1-\theta},
$$

which we call 'separable preference II'. We call 'separable preference I' the baseline separable preference defined over consumption and labor supply in equation (6). In (7), the relative utility weight on leisure is given by the parameter $\psi$, which is calibrated so that households allocate one third of their disposable time to market work on average as before. The IES is given by $\frac{1}{\theta} \frac{1-\ell}{\ell}$ and it varies over the lifecycle as a function of leisure relative to work hours at specific ages. We experiment with two values of $\theta$ at 4.0 and 2.0, which imply average IES values of 0.5 and 1.0, respectively.

The second utility function we consider in this section defines preferences that are non-separable in consumption and leisure,

$$
u(c, 1-\ell)=\frac{\left[c^{\nu}(1-\ell)^{1-\nu}\right]^{1-\sigma}}{1-\sigma} .
$$


The parameter $\nu$ represents the utility weight on consumption, calibrated to match the common target of work hours at 0.33 . We compute the model with two values of $\sigma$ at $1.0(\log )$ and 2.0, which imply the coefficient of relative risk aversion given as $1-\nu(1-\sigma)$ at 1.0 , the same as that in the baseline model, and 1.3 , respectively. This utility function has been used in most general equilibrium studies of social security reform. The Frisch elasticity in this case also varies over the life-cycle and depends on the ratio of leisure to work hours over the life-cycle. ${ }^{9}$

Once we calibrate models with different utility functions and parameter values to the common calibration targets, we repeat the simulation of the social security reforms. Our results of half privatization are summarized in Table 2.

Table 2: Aggregate effects of social security reforms: alternative preferences

\begin{tabular}{|l||r|r||r|r|}
\hline \multicolumn{1}{|l||}{ Preference } & \multicolumn{2}{c||}{ Separable II } & \multicolumn{1}{c|}{ Non-separable } \\
\hline$\theta$ & 4.0 & \multicolumn{1}{c|}{2.0} & \multicolumn{1}{c|}{-} & \multicolumn{1}{c|}{-} \\
$\sigma$ & - & - & 1.0 & 2.0 \\
Frisch elasticity & 0.5 & 1.0 & 2.0 & 1.3 \\
\hline PAYGO system (Benchmark) \\
\hline Labor income tax: $\tau^{l}+\tau^{s s}(\%)$ & $27.3 \%$ & $27.4 \%$ & $27.4 \%$ & $27.4 \%$ \\
\hline Half privatization & $+9.0 \%$ & $+8.4 \%$ & $+7.8 \%$ & $+12.1 \%$ \\
Capital & $+0.09 \%$ & $+0.23 \%$ & $+0.38 \%$ & $+1.06 \%$ \\
Labor & $+2.9 \%$ & $+2.6 \%$ & $+2.4 \%$ & $+3.5 \%$ \\
Wage & $22.6 \%$ & $22.7 \%$ & $22.7 \%$ & $22.2 \%$ \\
Labor income tax: $\tau^{l}+\tau^{s s}(\%)$ & $2.2 \%$ & $2.4 \%$ & $2.8 \%$ & $3.5 \%$ \\
Long-run welfare: $\mathrm{CEV}(\%)$ &
\end{tabular}

The first two columns of Table 2 show the results under separable preference II defined over consumption and leisure. If we compare these with the results in Table 1 , the aggregate effects are surprisingly similar across different utility functions. The increases in the aggregate capital stock are $9.0 \%$ and $8.4 \%$ under IES values of 0.5 and 1.0 here, respectively, and the corresponding numbers under separable preference I from Table 1 are $8.9 \%$ and $8.1 \%$. The wage and the labor income tax change by very similar magnitudes and the welfare effects are comparable under the

\footnotetext{
${ }^{9}$ The Frisch elasticity is given as $\frac{1-\ell}{\ell} \frac{1-\nu(1-\sigma)}{\sigma}$ and takes a value of 2.0 and 1.3 on average when $\sigma$ is set at 1.0 and 2.0 , respectively.
} 
two different forms of separable preferences. As before, the effect on aggregate labor supply is very small, with increases of only $0.09 \%$ and $0.23 \%$, respectively.

There is a large difference, however, in how the hours profile responds to social security reform. Note that with the form of preferences in (7), IES is not constant over the life-cycle and declines in market hours. Labor supply typically falls in pre-retirement ages in life-cycle models, which is also the case in our calibrated general equilibrium model. Therefore, the life-cycle effects that we observe under the baseline preferences with a constant IES in (6) will be magnified under these preferences. The reallocation of hours worked from early working ages to later working ages will be much larger under separable preferences II since individuals supply labor more elastically when they are closer to retirement than when they are prime aged. The left panel of Figure 3 shows the labor supply elasticity over the life-cycle under separable preference II with $\theta=2.0$. Hours worked just before retirement are much higher under the reform, but the effects under separable preferences II are even larger as shown in the left panel of Figure $4 .{ }^{10}$

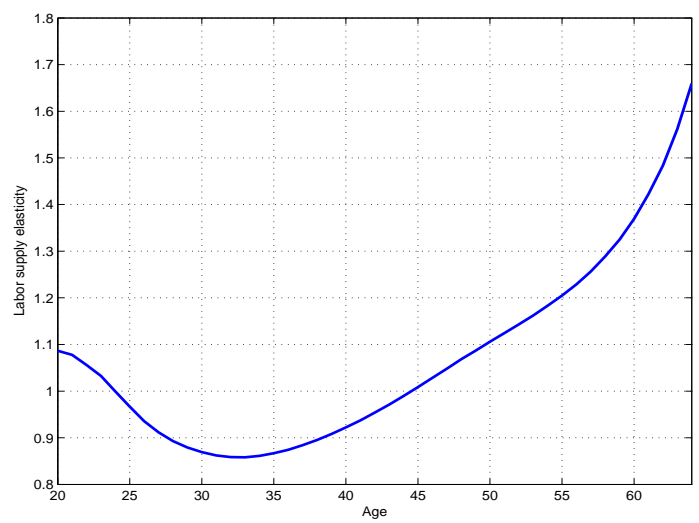

(a) Separable preference II with $\theta=2.0$

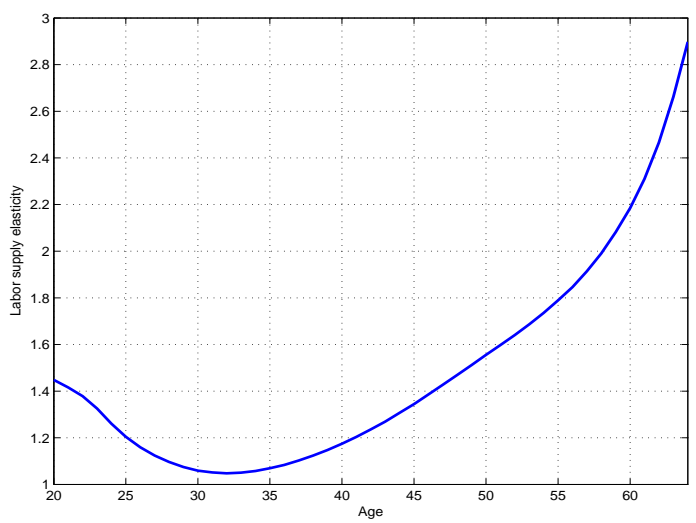

(b) Non-separable preference with $\sigma=2.0$

Figure 3: Labor supply elasticity over the life-cycle

\footnotetext{
${ }^{10}$ Note that the scale for the vertical axis is different from Figure 2. A complete set of numerical results (half and full privatization) under alternative utility functions and parameters and accompanying figures is available upon request from authors, which are not displayed here to save space.
} 


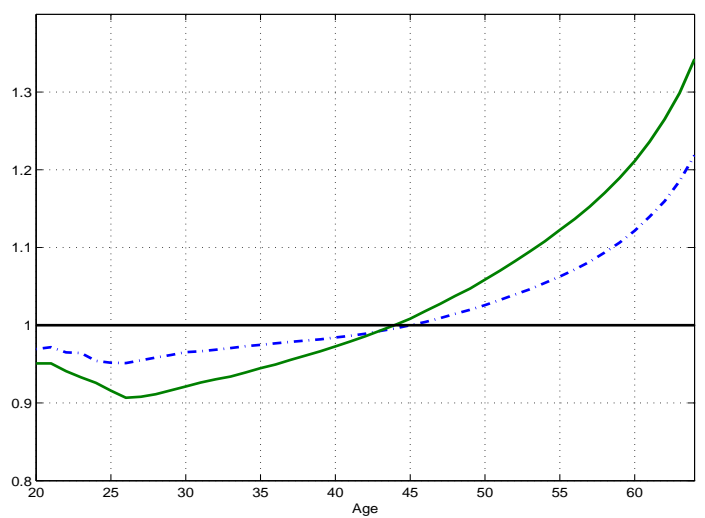

(a) Separable preference II with $\theta=2.0$

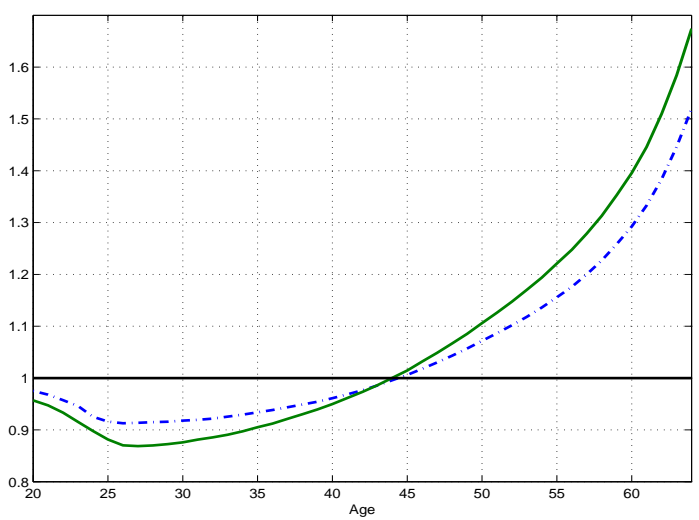

(b) Non-separable preference with $\sigma=2.0$

Solid lines represent the labor supply under full privatization relative to the benchmark PAYGO system and dashed lines half privatization.

Figure 4: Changes in labor supply over the life-cycle

The last two columns of Table 2 show the results with non-separable preferences with the value of $\sigma$ at $1.0(\log )$ and 2.0. The former value represents the coefficient of relative risk aversion at 1.0, corresponding to that under the separable preferences I and II that we considered above. If we compare the results of $\sigma=1.0$ with those of separable preferences, the aggregate effects are quantitatively similar. In the half privatization reform, aggregate capital stock increases by $7.8 \%$ and the combined labor income tax rate falls to $22.7 \%$. The welfare effects are also similar, at $2.8 \%$ in consumption equivalent variation. The change in aggregate labor is small as in other specifications, a slight increase of $0.38 \%$. With non-separable preferences, the fall in consumption at older ages under reforms will reduce the disutility from work, while there is no such direct effect under separable preferences. Therefore it induces even more work when households are older and contributes to a larger increase in aggregate labor supply.

As shown in the last column of Table 2, when $\sigma$ is set at 2.0 and the relative risk aversion is higher (and intertemporal elasticity of substitution is lower), the aggregate effects are much larger. Aggregate capital increases by $12.1 \%$, relative to $7.8 \%$ with $\sigma=1.0$. With a lower intertemporal elasticity of substitution, households are less willing to accept a decline of consumption at older ages due to the reform and respond to it by raising their saving even more. The labor supply will also respond by more than that in the case with lower $\sigma$. Due to the additional utility 
from a large increase in consumption, which offsets the higher disutility from more work, the welfare gain is larger with $\sigma=2$.

\subsection{Effects of demographic change and social security re- forms}

In this section, we study the sensitivity of our results under different demographic structures. In particular, we investigate how our findings about the effects of different values for IES on the quantitative predictions of social security reform will change when we incorporate the projected aging of the population into the models. Instead of assuming the stationary demographic structure in 2005 summarized by current survival rates and dependency ratio, we run the reform experiments using the demographic variables for 2080, based on projected conditional survival rates and the predicted 2080 dependency ratio. As mentioned in section 3, we use Bell and Miller (2005) for the projected survival rates and set the population growth rate at $0.1 \%$, which together with the increased longevity implies an old-age dependency ratio of $40 \%$ in 2080, twice as large as $20 \%$ used in the baseline simulations. In what follows, we call this new economy with more elderly and higher longevity as the economy with aging.

Before analyzing the effects of social security reforms, we will briefly describe the effects of the demographic change by itself. Table 3 summarizes the changes in the aggregate statistics in the economy with aging, where the current pay-as-you-go social security system is maintained.

Table 3: Effects of the demographic change relative to the benchmark economy without aging

\begin{tabular}{|l||r|r|r|r|}
\hline IES gamma & \multicolumn{1}{|c|}{0.1} & \multicolumn{1}{c|}{0.5} & \multicolumn{1}{c|}{1.0} & \multicolumn{1}{c|}{2.0} \\
\hline Capital (per capita) & $-7.6 \%$ & $-7.4 \%$ & $-7.5 \%$ & $-7.9 \%$ \\
Labor (per capita) & $-14.4 \%$ & $-13.8 \%$ & $-13.6 \%$ & $-13.5 \%$ \\
Average work hours & $+0.4 \%$ & $+1.1 \%$ & $+1.4 \%$ & $+1.6 \%$ \\
Wage & $+2.6 \%$ & $+2.4 \%$ & $+2.3 \%$ & $+2.1 \%$ \\
Interest rate (\%) & $6.0 \%$ & $6.0 \%$ & $6.1 \%$ & $6.1 \%$ \\
Labor income tax: $\tau^{l}+\tau^{s s}(\%)$ & $37.4 \%$ & $37.4 \%$ & $37.4 \%$ & $37.5 \%$ \\
\hline
\end{tabular}

The higher dependency ratio increases the cost of providing pension benefits 
at the benchmark levels and the combined labor income tax will rise by about 10 percentage points to $37 \%$. Since the fraction of working population falls, per-capita labor supply in the economy falls significantly, by about $14 \%$. The decrease in the interest rate, caused by a large increase in the aggregate capital-labor ratio, will lower the optimal growth rate of consumption and flatten its life-cycle profile. As a result, private saving will fall and reduce the aggregate capital stock compared to the benchmark economy. Also note that despite the large increase in the labor income tax rate, average work hours increase although the magnitude is small, at most $1.6 \%$ with $\gamma=2.0$. The substitution effect due to the lower after-tax wage rate is offset by the income effect due to the lower level of consumption. Similar to the effect of privatization that we examined in previous sections, a lower interest rate will flatten not only the consumption profile but also the age-hours profile, and more productive households in older ages will provide a higher work effort.

Now we turn our attention to the effect of social security reform in the economy with aging. Table 4 summarizes the effects of half privatization, where the numbers are expressed in terms of the distance from the economy with aging but with unfunded social security, the economy that we just studied above.

Table 4: Effects of a reform in the economy with aging

\begin{tabular}{|l||r|r|r|r|}
\hline Frisch elasticity $\gamma$ & \multicolumn{1}{|c|}{0.1} & \multicolumn{1}{c|}{0.5} & 1.0 & \multicolumn{1}{c|}{2.0} \\
\hline Half privatization & $+17.0 \%$ & $+16.5 \%$ & $+15.9 \%$ & $+15.0 \%$ \\
\hline Capital & $+0.1 \%$ & $+0.4 \%$ & $+0.8 \%$ & $+1.1 \%$ \\
Labor & $+0.1 \%$ & $+0.4 \%$ & $+0.7 \%$ & $+1.2 \%$ \\
Average work hours & $+5.3 \%$ & $+5.0 \%$ & $+4.7 \%$ & $+4.3 \%$ \\
Wage & $4.7 \%$ & $4.8 \%$ & $4.9 \%$ & $5.0 \%$ \\
Interest rate (\%) & $27.6 \%$ & $27.5 \%$ & $27.4 \%$ & $27.4 \%$ \\
Labor income tax: $\tau^{l}+\tau^{s s}(\%)$ & $8.0 \%$ & $8.6 \%$ & $9.2 \%$ & $10.0 \%$ \\
Long-run welfare: $\mathrm{CEV}(\%)$ & & & & \\
\hline
\end{tabular}

Compared to the effects in the benchmark economy without aging in Table 1, qualitative effects on aggregate variables and the impact of different elasticities are very similar. The magnitude, however, is very different. Half privatization raises aggregate capital by 15.0 to $17.0 \%$ depending on IES, compared to 7.2 to $9.6 \%$ in the benchmark economy without aging. Households live longer in this economy and if the public pension is cut in half, they would have to accumulate much more savings 
for retirement on their own. Due to the massive increase in aggregate capital, the interest rate will decline by more, which flattens the profiles of consumption and labor supply further compared to the benchmark. Due to the large positive effect on output and consumption as a result of the larger capital stock of the economy, the long-run welfare gain is much larger as well.

\section{Conclusion}

The intertemporal elasticity of substitution in labor is a crucial parameter in determining the response of labor supply to changes in policy and factor prices. Early empirical estimates by Altonji (1986) and MaCurdy (1981) suggest that labor supply is quite inelastic. More recent structural estimates utilized departures from the earlier representative agent models and also incorporated data other than primeage males. The typical outcome was an IES around unity, with some estimates as high as 3.8 (Imai and Keane, 2004). On the macroeconomics side, early work by Kydland and Prescott (1982) relied on a high IES as the propagation mechanism of the business cycles in their neoclassical theory. Recent work by Prescott (2004) also argues for a high IES to explain the difference in average market hours between the U.S. and European countries.

In this paper, we explore the role of IES in shaping the quantitative results of social security reform. Our setup is a general equilibrium model populated with overlapping generations of individuals who face uninsurable income risk, mortality risk and borrowing constraints. Individuals choose hours worked until the mandatory retirement age, in addition to the usual consumption-saving decision over the life-cycle. We consider three classes of preferences that have been used in the applied labor, real business cycle, and public finance strands of the literature. For each period utility function, we evaluate the quantitative results of social security reform using a range of values for the IES commonly estimated and used in previous research. In each case, we calibrate the model to the same aggregate targets consistent with features of the U.S. economy over the past five decades.

We have two main findings. First, a particular period utility function and the value for the IES have a negligible impact on the aggregate effects of social security reform. In all cases considered, reform results in an increase in the capital stock which is within a percentage point or two over the range of IES coefficients used. Aggregate labor supply is essentially unchanged in the long-run, consistent with the earlier findings of the overall canceling out of income and substitution effects in the long-run. However, reform generates a significant reallocation of hours worked over 
the life-cycle. This brings us to the second main finding of the paper. The increase in the capital-labor ratio fueled by social security reform lowers the real interest rate and flattens the life-cycle profile of labor supply. Individuals shift work hours from younger years to older years before they retire. This reallocation is quantitatively more significant with a higher IES. Therefore the value of IES used in analyzing social security reform has important implications on how individuals allocate hours over their life-cycle and the composition of labor supply of the economy.

Finally, although our model has focused on the adjustment of labor supply at the intensive margin, we conjecture that the value of IES may also influence the participation and retirement decisions. Further investigating the effects on both intensive and extensive margins calls for a model that endogenizes participation decisions. We will investigate these important issues in ongoing research. 


\section{References}

Altonji, J. G. (1986). Intertemporal substitution of labor supply: Evidence from microdata. Journal of Political Economy 94(3), 176-215.

Bell, F. C. and M. L. Miller (2005). Life tables for the United States social security area 1900-2100. Office of the Chief Actuary, Social Security Administration, Actuarial Study 116.

Boldrin, M. and A. Rustichini (2000). Political equilibria with social security. Review of Economic Dynamics 3(1), 41-78.

Casamatta, G., H. Cremer, and P. Pestieau (2002). The political economy of social security. Scandinavian Journal of Economics 102(3), 503-522.

Conesa, J. C. and D. Krueger (1999). Social security with heterogeneous agents. Review of Economic Dynamics 2(4), 757-795.

Cooley, T. and J. Soares (1999). A positive theory of social security based on reputation. Journal of Political Economy 107(1), 135-160.

De Nardi, M., S. İmrohoroğlu, and T. J. Sargent (1999). Projected U.S. demographics and social security. Review of Economic Dynamics 2(3), 575-615.

Feldstein, M. (1985). The optimal level of social security benefits. Quarterly Journal Economics 100, 303-320.

Fuster, L., A. İmrohoroğlu, and S. İmrohoroğlu (2007). Elimination of social security in a dynastic framework. Review of Economic Studies 74(1), 113-145.

Hansen, G. D. (1993). The cyclical and secular behaviour of the labour input: Comparing efficiency units and hours worked. Journal of Applied Econometrics $8(1), 71-80$.

Heathcote, J., K. Storesletten, and G. L. Violante (2004). The macroeconomic implications of rising wage inequality in the United States. Working paper, New York University.

Huang, H., S. İmrohoroğlu, and T. J. Sargent (1997). Two computations to fund social security. Macroeconomic Dynamics 1, 7-44.

Hubbard, R. G. and K. Judd (1987). Social security and individual welfare: Precautionary saving, borrowing constraints, and the payroll tax. American Economic Review 177(4), 630-646.

Imai, S. and M. P. Keane (2004). Intertemporal labor supply and human capital accumulation. International Economic Review 45(2), 601-641. 
İmrohoroğlu, A., S. İmrohoroğlu, and D. Joines (1995). A life cycle analysis of social security. Economic Theory 6(1), 83-114.

İmrohoroğlu, A., S. İmrohoroğlu, and D. Joines (2003). Time inconsistent preferences and social security. Quarterly Journal of Economics 118(2), 745-784.

Kotlikoff, L., K. Smetters, and J. Walliser (1999). Privatizing social security in the united statescomparing the options. Review of Economic Dynamics 2(3), $532-574$.

Kydland, F. E. and E. C. Prescott (1982). Time to build and aggregate fluctuations. Econometrica 50 (6), 1345-1370.

MaCurdy, T. E. (1981). An empirical model of labor supply in a life-cycle setting. Journal of Political Economy 89(6), 1059-1085.

McGrattan, E. R. and R. Rogerson (2004). Changes in hours worked since 19502000. Federal Reserve Bank of Minneapolis, Quarterly Review 28(1), 14-33.

Nishiyama, S. and K. Smetters (2007). Does social security privatization produce efficiency gains? Quarterly Journal of Economics 122(4), 1677-1719.

Prescott, E. C. (2004). Why do Americans work so much more than Europeans? Federal Reserve Bank of Minneapolis, Quarterly Review 28(1), 2-15.

Rogerson, R. and J. Wallenius (2007). Micro and macro elasticities in a life cycle model with taxes. Working paper, Arizona State University. 


\section{RECENT WORKING PAPERS FROM THE}

\section{CENTER FOR RETIREMENT RESEARCH AT BOSTON COLLEGE}

Evaluating Micro-Survey Estimates of Wealth and Saving

Barry P. Bosworth and Rosanna Smart, January 2009

Portfolio Choice in Retirement: Health Risk and the Demand for Annuities, Housing, and Risky Assets

Motohiro Yogo, January 2009

The Disappearing Defined Benefit Pension and its Potential Impact on the Retirement Incomes of Boomers

Barbara A. Butrica, Howard M. Iams, Karen E. Smith, and Eric J. Toder, January 2009

Retirement and Social Security: A Time Series Approach

Brendan Cushing-Daniels and C. Eugene Steuerle, January 2009

Economic Restructuring and Retirement in Urban China

John Giles, January 2009

Sources of Support for Pension Reform: A Cross-National Perspective

Michelle Dion and Andrew Roberts, January 2009

The Long-Term Effect of the Divorce Revolution: Health, Wealth, and Labor Supply

Kristin Mammen, December 2008

The Response of Household Saving to the Large Shock of German Reunification Nicola Fuchs-Schündeln, November 2008

A Parsimonious Choquet Model of Subjective Life Expectancy

Alexander Ludwig and Alexander Zimper, November 2008

Risky Pensions and Household Saving Over the Life Cycle

David A. Love and Paul A. Smith, November 2008

Identifying Local Differences in Retirement Patterns

Leora Friedberg, Michael Owyang, and Anthony Webb, November 2008

What Effect Do Time Constraints Have on the Age of Retirement?

Leora Friedberg, Wei Sun, Anthony Webb, November 2008 